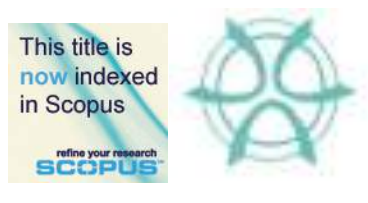

PLANNING MALAYSIA:

Journal of the Malaysian Institute of Planners

SPECIAL ISSUE IV (2016), Page 135 - 146

\title{
FACTOR ANALYSIS OF MOTORCYCLE CRASHES IN MALAYSIA
}

\author{
Zahid Sultan ${ }^{1}$, Noor Irdiana Ngadiman ${ }^{2}$, Fara Dela A.Kadir ${ }^{3}$, Nuur Fathin Roslan ${ }^{4}$ \\ \& Mehdi Moeinaddini ${ }^{5}$ \\ 1,2,3,4,5 Faculty of Built Environment \\ UNIVERSITI TEKNOLOGI MALAYSIA
}

\begin{abstract}
This research paper focused on factor analysis of motorcycle crashes in Malaysia. Statistics have shown that Malaysia has the highest road fatality risk (per 100,000 populations) among the ASEAN countries and more than 50\% of the road accident fatalities involve motorcyclists. The research literature has shown that key factors that significantly involve in the motorcycles crashes are human factors, road and vehicle conditions and environment factors. The purpose of this research is to analyse the driving attitude, behaviour and habits of Malaysian motorcyclists especially the young students. For this purpose, a research survey $(\mathrm{N}=210)$ has been conducted in University Technology Malaysia (UTM) in order to perceive road user perception on key factors that contribute to motorcycle crashes in Malaysia among the young students. The results show that the highest factor that contributes to the motorcycle crashes in Malaysia is the human behavior factor, follow by road and vehicle and lastly the environment factor. Human attitude on the road is the main factor that causes a motorcycle crash. Impatience, careless, selfish and dangerous driving make driver involve an accident. Evidence recommendations are suggested to reduce the number motorcycle crash in Malaysia. Implementation of these recommendations can be helpful to reduce the number of accidents and changing the attitude of young driver.
\end{abstract}

Keyword: Motorcycle Crashes, Malaysia, Human Factors, Road Factor, Environment Factors, Social Factors, Vehicle Factors

\section{INTRODUCTION}

The motorcycle has become popular in certain developing and middle countries and be the most common mode of transportation in Malaysia, Taiwan, Thailand and Vietnam. The relatively low price of motorcycles and their low fuel consumption are among the reasons why motorcycles are so popular in these countries. Due to increasing usage, the number of motorcycle accidents and related fatal injuries in these countries are also increasing. (Nur Sabahiah A.S and Satoshi Fujii, 2011) Accidents happen as a result of the combination of several factors and are often not caused by a single cause. According to the World Health Organization's (WHO's) road traffic injuries defined as "fatal or nonfatal injuries incurred as a result of a road traffic crash" and road traffic crash is defined as "collision or incident that may or may not lead to injury, occur on a public road and involving at least one moving vehicle" (Ghazali Masuri and Khairil Anuar, 2011). 
Zahid Sultan, Noor Irdiana Ngadiman, Fara Dela A.Kadir, Nuur Fathin Roslan \& Mehdi Moeinaddini Factor Analysis of Motorcycle Crashes in Malaysia

Road injuries and fatalities are a growing concern in Malaysia, with more than 6000 killed and over 25,000 recorded injuries yearly for the past 5 years. As the total of motorcycle billion kilometres travelled in Malaysia increased from 1999 to 2008, motorcycle fatalities increased as well which indicates that motorcycle casualties are affected by the increase in exposure. Motorization in Asian countries is growing fast and the motorcycle is the dominating transport mode. The number of motorcycles per thousand people averaged over several major Asian cities is approximately 196, which is 7 times the average of the rest of the world.

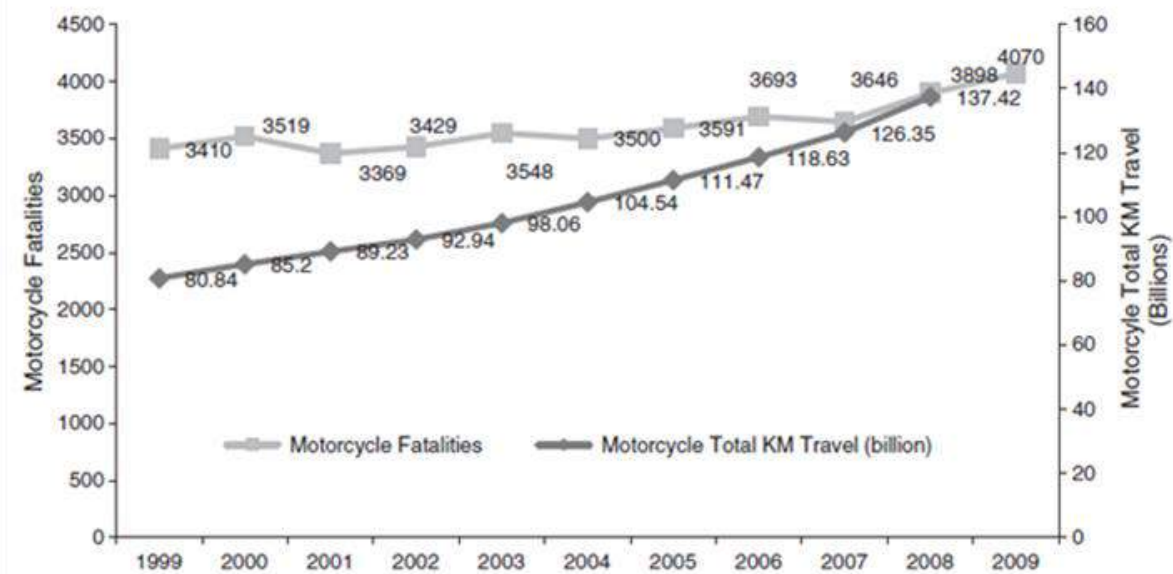

Figure 1: Total motorcycle kilometers travelled and motorcycle fatalities between 1998 and 2008

(Sources: Motorcycle fatalities in Malaysia, Muhammad Marizwan Abdul Manan and András Várhelyi, 2012)
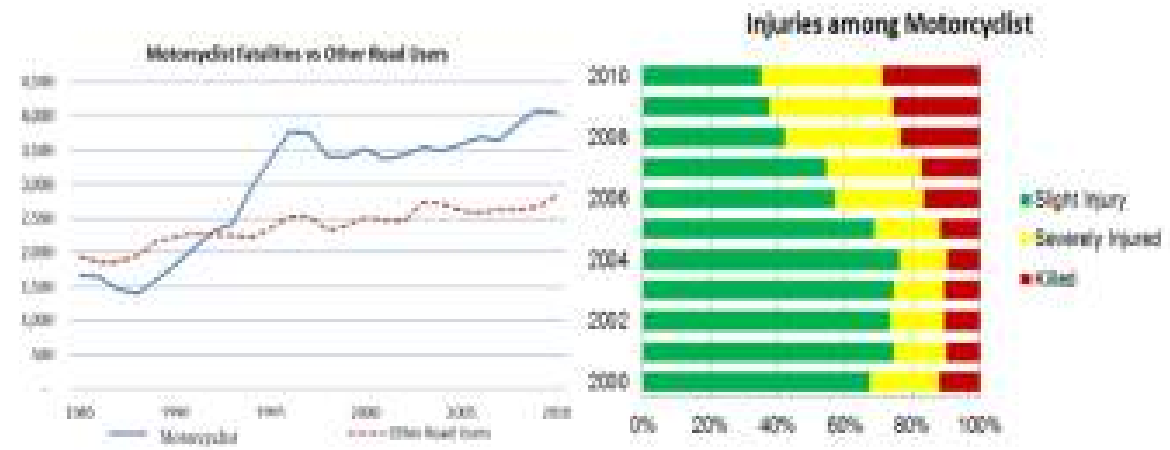

Figure 2: Motorcyclist fatalities vs other road users and injuries among motorcyclist in Malaysia until year 2010

(Sources: Monash University Accident research Centre)

In Malaysia, motorcycles offers a cost effective means of travel and represent around $45 \%$ registered vehicles and a motorcycle license is available to young adults from 
16 year olds and above.In addition, the number of registered motorcycles in Taiwan comprises $50 \%$ of the total number of registered vehicles, in Thailand it is $63 \%$, in Cambodia 84\%, in Vietnam 95\%, in Laos 79\% and in Indonesia 73\%. Malaysia, with a population of 27.6 million, is not an exception.. According to The Road Transport Department of Malaysia, the total number of motorcycles in 2009 was 8,940,230 (47\% of all motorised vehicles), which was $5 \%$ more than passenger cars. The proportion of the motorcycle population on Malaysian roads varies from state to state. The motorcycle is the major mode of personal transport for the low-income urban community. In general, motorcycles are the major contributor to road fatalities in the country, with no sign of declining in the near future. Moreover, motorcyclists have a higher fatality rate per distance travelled than other vehicles; for example, in 2004, there were 32.2 fatalities per billion kilometres travelled whereas for passenger cars it was 8.39 fatalities per billion. (Muhammad Marizwan Abdul Manan and András Várhelyi, 2012).The are many factors that affecting the motorcycle crashes which is human factors, road environemnt factors, vehicle factors.

According to Monash University Accident research Centre, 2013, 95\% crash involvement factors are come contributed from human factors. Based on the telephone survey of 1922 participants, human factors are consists of driver's behaviour and attitudes which is not implement helmet wearing, overtaking on the left, riding in the emergency lane, running ref lights, ride in between moving cars, close behind trucks, spedding behaviours, smoking and use of handphone. In addition, road environemnt factors are contribute $28 \%$ as total and vehicles factors is $8 \%$.

\section{LITERATURE REVIEW}

\section{HUMAN FACTORS}

Based on the above figure, Malaysia is the top ten countries with highest number of motocyclers per 1000 population. Motorcycle riders are considers the most crucial component in motorcycle riding. According to Laksanakit C, 2013, over the period of 1996-2006 the numbers of motorcycle fatality in USA had doubled and the major contribution factors were human errors. Speeding and high alcohol level in blood hit the peak of motorcycle crash causation. 
Zahid Sultan, Noor Irdiana Ngadiman, Fara Dela A.Kadir, Nuur Fathin Roslan \& Mehdi Moeinaddini Factor Analysis of Motorcycle Crashes in Malaysia

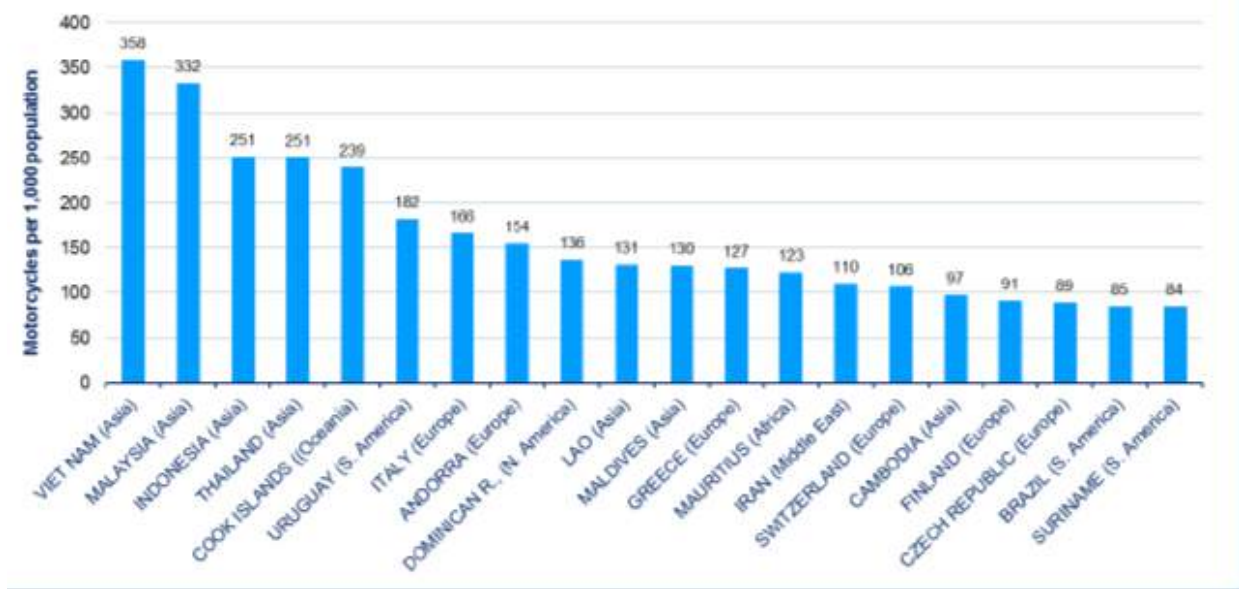

Figure 3: The leading 20 countries with high number of motorcycles per 1000 population

(Sources: Laksanakit, 2013, compiling from WHO 2013 data)

Based on the above figure, Malaysia is the top ten countries with highest number of motocyclers per 1000 population. Motorcycle riders are considers the most crucial component in motorcycle riding. According to Laksanakit C, 2013, over the period of 1996-2006 the numbers of motorcycle fatality in USA had doubled and the major contribution factors were human errors. Speeding and high alcohol level in blood hit the peak of motorcycle crash causation.

However, for the motorcycle accident situation in South East Asia, the trend in fatality rate in motorcycle accidemt in Malaysia has contributed to grow since early 90's. Careless driving was the biggest propotion of driver's faults that affected fatality rate of motorcycle crashes. It was noticeable that a vilation to traffic light by motorcycle riders had increased about threefolds. In addition, in Thailand, the key findings was found that young motorcycle riders had poor safe driving behaviour. Their habit of poor driving need to be improved. Besides that, the young motorcyclists in the 18-35 age group tend to violate traffic laws more than other age groups.moreover, the key risk elements is the inexperience of riders would seem a primary contributing factors to motorcycle crashes. The other human factors found that alcohol was a major casue of motorcycle crashes in Thailand. Most of alcohol effects were evident in the loss of control motorcycle crashes resulting in run off the road or single vehicle crash. (Laksanakit C, 2013).

According to Nur Sabahiah A.S and Satoshi F, 2011, the top cause of motorcycle collision fatalities in Malaysia is head damage resulting from not wearing a helmet. The authors claimed that motorcycle helmets could reduce the risk of head injury up to $72 \%$. In Malaysia, $62.9 \%$ of all documented injuries that resulted in death for motorcyclists involved head injuries. As report in the Research Report for National Road Safety Council, in the absence of police, only $55 \%$ of motorcyclist wore helmets properly in 1995 and only $41 \%$ did so in 1998 . Another study reported that $54.4 \%$ of motorcyclists wore a helmet properly, $13.6 \%$ wore a helmet tied loosely, $8.0 \%$ wore an untied helmet and $24.0 \%$ did not wear the helmet in rural areas. 
The further investigate the casue of motorcycle accidents in Malaysia is the factors that influence the occurrence of speeding behavior must be empahasized. The higher the speeding acceleration, the greater the velocity change while braking, this increased velocity change while braking increases the severity of injuries. Therefore, it has been suggested thet reducing traveling speeds might reduce injury severity during a crash. The suggestion is supported by a study that shows that riding over $60 \mathrm{~km} / \mathrm{h}$ could cause severe injuries to motorcyclists rather than riding at lower speeds (Nur Sabahiah A.S and Satoshi F, 2011).

\section{ROAD / TRAFFIC FACTORS}

Malaysia's motorcycle fatalities are not among the worst in the Association of South East Asian Nations, ASEAN. Motorcycles constitute approximately 58\% of the vehicles in ASEAN countries, and over the last decade the motorcycle has been the major contributor, with $52 \%$, to road traffic fatalities. From the research, resercher have compare motorcycle fatalities per 10,000-registered motorcycles in each country, Malaysia ranks seventh as per table above. The three highest are Cambodia (75.1), Lao P.D.R (9.6) and Singapore (7.1) in terms of motorcycle fatalities per 10,000 registered motorcycles. However, Malaysia has the highest number of road fatalities per 100,000 population. (Sources: Motorcycle fatalities in Malaysia, Muhammad Marizwan Abdul Manan and András Várhelyi, 2012)

Table 1: Road Traffic Safety Data from ASEAN Countries

\begin{tabular}{|c|c|c|c|c|c|c|c|c|}
\hline \multirow[t]{2}{*}{ No } & \multirow[t]{2}{*}{$\begin{array}{l}\text { ASEAN } \\
\text { countries }\end{array}$} & \multirow[t]{2}{*}{$\begin{array}{l}\text { Population } \\
(2007)\end{array}$} & \multicolumn{2}{|c|}{$\begin{array}{l}\text { Registered motorcyde } \\
(2 \omega 27)\end{array}$} & \multicolumn{2}{|c|}{$\begin{array}{l}\text { Reparted fatalities } \\
(2007)\end{array}$} & \multirow{2}{*}{$\begin{array}{l}\text { Road fitalities } \\
\text { per } 100,000 \\
\text { population }\end{array}$} & \multirow{2}{*}{$\begin{array}{l}\text { Motoryde Gatalitios } \\
\text { per } 10000 \text { tegistered } \\
\text { motortycles }\end{array}$} \\
\hline & & & Total (millos) & (3) & Total & $(x)$ & & \\
\hline 1 & Brunei & 390056 & 0.01 & 4 & 54 & 11 & 138 & 49 \\
\hline 2. & Singpore & 4,436281 & 0.14 & 17 & 214 & 48 & 48 & $7.1(3)$ \\
\hline 3 & LooPDg. & 5.859393 & 0.51 & 79 & 608 & $\$ 0$ & 104 & $26(2)$ \\
\hline 4 & Canbodia & 14,443679 & 0.13 & 84 & 1545 & 63 & 10,3 & $x .1(1)$ \\
\hline 5 & Maluysia & 26571879 & 7.91 & 47 & 6282 & 58 & $236(1)$ & 46 \\
\hline 6 & Myzamur & 48,798212 & 0.08 & 65 & 1638 & 10 & 34 & 24 \\
\hline 7 & Muland & 63883662 & 16.14 & ๘3 & 12,492 & $x$ & $195(2)$ & 54 \\
\hline 8 & Vietnum & 87375.196 & 21.78 & 9 & 12800 & 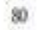 & $145(3)$ & 47 \\
\hline 9 & Philippines & 87960.117 & 2.65 & 48 & 1185 & 37 & 1.3 & 1.7 \\
\hline \multirow[t]{2}{*}{10} & Indaresia & 231,526978 & 46.22 & 73 & 16548 & 6 & 7.1 & 2.2 \\
\hline & Toal & 571345,453 & 96.17 & 58 & 53366 & 52 & & \\
\hline 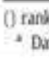 & $\begin{array}{l}\text { in categon, } N \\
006\end{array}$ & reyde & & & & & & \\
\hline
\end{tabular}

Malaysia's West Coast States have the highest number of motorcycle fatalities and fatality rate per 100,000 populations. The East Coast Region, with a lower motorcycle population and less built-up density, has the highest fatality rate per 10,000 motorcycles. Meanwhile, the Federal Territories, which have the highest population density, record the lowest rate in motorcycle fatality per 10,000 registered motorcycles. Overall, police records show that $61 \%$ of these fatalities occur in rural areas while cities record only $8 \%$. Looking deeper into the type of area, motorcycle fatalities are mostly recorded on motorways and primary roads $(62 \%)$. Apart from this, motorcycles fatalities are also found more in residential areas (20\%), as compared to other types of areas shows that the majority of motorcycle fatalities occur on arterial or primary roads. Related to the road 
Zahid Sultan, Noor Irdiana Ngadiman, Fara Dela A.Kadir, Nuur Fathin Roslan \& Mehdi Moeinaddini Factor Analysis of Motorcycle Crashes in Malaysia

length, the highest fatality rate per $100 \mathrm{~km}$ and per 100,000 motorcycles also occurs along primary or arterial roads. Moreover, there are more motorcycle fatalities per $100 \mathrm{~km}$ of Malaysian primary roads than on secondary roads, local streets and minor roads combined.

Table 2: Motor Fatality by Road Type in Malaysia in 2009 Motorcycle fatality by road type in Malaysia in $2009[1,8,26]$.

\begin{tabular}{|c|c|c|c|c|c|c|c|c|}
\hline \multirow[t]{2}{*}{ Road hierarchy } & \multicolumn{2}{|c|}{ Road length } & \multicolumn{2}{|c|}{$\begin{array}{l}\text { ADT } \\
\text { (million) }\end{array}$} & \multicolumn{2}{|c|}{$\begin{array}{l}\text { MC } \\
\text { fatalities }\end{array}$} & \multirow[t]{2}{*}{$\begin{array}{l}\text { MC fatal/ } \\
100 \mathrm{~km}\end{array}$} & \multirow{2}{*}{$\begin{array}{l}\text { MC fatal/ } \\
100,000 \\
\text { MC }\end{array}$} \\
\hline & $\mathrm{km}$ & $\%$ & Veh & MC & $\mathrm{N}$ & $\%$ & & \\
\hline Expressway & 1635 & 1.3 & 20.6 & * & 121 & 3.0 & 7.4 & $*$ \\
\hline Primary/arterial & 16,939 & 13.6 & 12.8 & 2.6 & 2021 & 49.7 & 11.9 & 76.7 \\
\hline Secondary/collector & 54,681 & 43.9 & 6.3 & 1.6 & 672 & 16.5 & 1.2 & 42.0 \\
\hline Local street & 43,363 & 34.8 & $*$ & * & 755 & 18.6 & 1.7 & $*$ \\
\hline Minor roads & 8038 & 6.4 & * & * & 501 & 12.3 & 6.2 & $*$ \\
\hline Total & 124,656 & 100 & - & - & 4070 & 100 & 3.3 & - \\
\hline
\end{tabular}

ADT - average daily traffic, Veh - vehicle, MC - motorcycle,

$\left({ }^{*}\right)$ - data is not available.

The traffic count (ADT) covers $70 \%$ of each road hierarchy in Malaysia.

(Sources: Motorcycle fatalities in Malaysia, Muhammad Marizwan Abdul Manan and András Várhelyi, 2012)

The great majority of motorcycles fatalities are reported on straight road sections. Fatal accidents involving motorcycles are three times as high on straight road sections compared to the curved sections. Staggered junctions, interchanges and roundabouts have the lowest number of fatalities, recording less than $1.0 \%$ fatalities each in 2009.
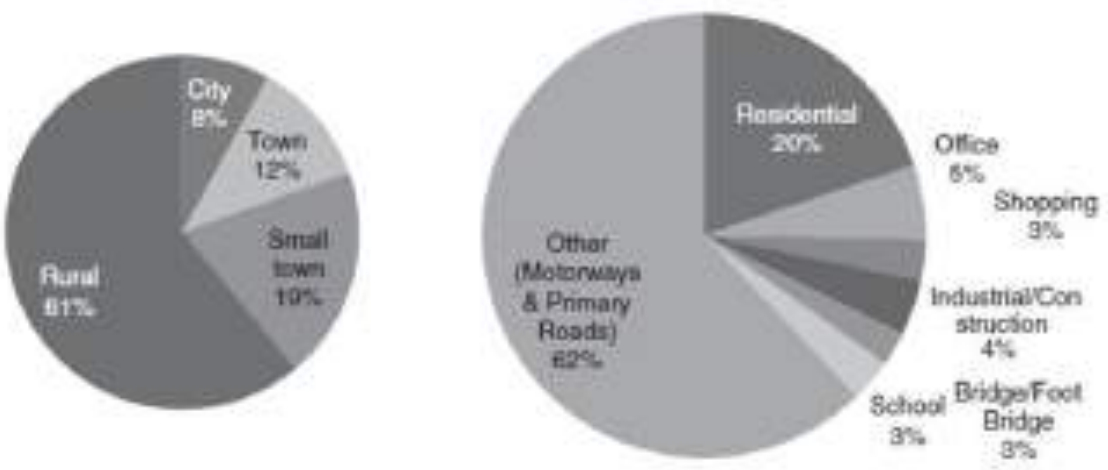

Figure 4: Motorcycle fatality based on area type

(Sources: Motorcycle fatalities in Malaysia, Muhammad Marizwan Abdul Manan and András Várhelyi, 2012) 


\section{ENVIRONMENTS FACTORS}

One of the factors that contribute to the accident in Malaysia is the environment. Some researcher prefers the term of environment as the weather condition that give effect to the road condition that contribute to the accident. Fine weather does not itself affect driving adversely as the major of the accident occur during this time. The weather also can give the impact regarding to the location of road between urban area and rural area. Rural authority tends to record highest ratio of accident during bad weather. Generally urban area has great traffic densities and a higher level of infrastructure than rural area. Rural area however tend to have less traffic and fewer vehicles on the road. Consequently rural motorists are able to drive at higher speed owning to less traffic and often on poorer roads that were not design for the speed. Rain is the most common weather give affects, accident frequency increase in wet weather condition. The risk of being accident actually can be reduce when the accident occur in rain compare with fine weather, driver may take more care in wet condition by adjusting their speed and driving habits accordingly. However during the rainfall a great number of vehicles involve in minor collisions cause driver not taking into consideration the result of wet road surface. High wind may affect a vehicle's either directly by causing the vehicles to deviate from its course, turn over or indirectly by obstruction dangerous being present in the road such as fallen trees or walls and panelling being blown over (Julia, 1998)

Some researcher prefer the term of environment as the condition of the road. Ministry of Works, Malaysia highlights four approaches in their Road Safety Program in order to improve the road safety, the following engineering approaches have been utilized .Accident preventions, accident reduction, road maintenance and building new roads. In theory, when the users can eliminate or reduce their time or exposure on the road, the possibility of being involved in accidents is reduces. Roads should be built to suit their function and this is the approach used by developed countries such as Denmark and Netherland which seem successful in reducing accidents. In Malaysia, the increase in road accidents is linked to the rapid growth in population, economic, industrialization and motorization industries (Ghazali Masuri and Khairil Anuar, 2011).

Another opinion of researcher, the environment is referring to the location of the road. Research has found the majority of Malaysia motorcycle accident occurs along straight road section and fatal side collision. The present study have shown that road environment influence on the occurrence of traffic conflicts involving motorcycle entering from access point and merging with traffic on primary road in Malaysia (Marizwan Abdul Manan, 2014). Based on the previous research it has shown that there are several factors that contribute to the road accident in Malaysia. The main factors analysis of motorcycles crashes in Malaysia are from human factors, road and traffic factors and also environments factors. In this study reveal the impact of psychological human factors on motorcyclists's speeding anf helmet usage behaviours in Malaysia (Nur Sabahiah A.S and Satoshi F,2011). Motorcyclists still lack of awareness rgarding the important of helmet usage especially in rural area because at rural area still lack of police or authority enforcement. Besides that, the attitute towards speeding behaviour. Motorcyclist usually like to overtaking and over speeding because their assume there are small and ease to move, but the danger movement are cause an road accidents.

In Malaysia, motorcycle lanes have been constructed to segregate motorcyclists from other motor vehicles. This study examined the effects of different types of 
Zahid Sultan, Noor Irdiana Ngadiman, Fara Dela A.Kadir, Nuur Fathin Roslan \& Mehdi Moeinaddini Factor Analysis of Motorcycle Crashes in Malaysia

motorcycle lanes on motorcyclists' speeding action and their psychological factors. Speeding behavior was chosen due to the increased risk of motorcycle fatality usually associated with speed action (Pang et.al, 1999; Haglund and Aberg, 2000; Lin et.al, 2003). The findings from this study demonstrated that the exclusive motorcycle lane has the highest impact on encouraging the speeding behaviour, followed by the inclusive lane and then the paved shoulder. Another type motorcycle lane that usually constructed in Malaysia is non-exclusive motorcycle lane which built on the left side of the existing road on federal or state roads. Physical barrier or pavement marking formed in order to define the corridor as a set aside for motorcyclists. Nowadays, 11 sites within federal road have been constructed with non-exclusive motorcycle lanes and several more are in construction progress with cost RM36 million. According to A Guide on the Design of Cycle Track (1986), the speed limit that appropriate for both exclusive and inclusive lanes is $60 \mathrm{~km} / \mathrm{h}$. Meanwhile, paved shoulder is another type of non exclusive motorcycle lane that does not have designated pavement marking and barrier that actually functions as lateral support for the pavement. The use of the paved shoulder by motorcyclists is made mandatory by law and other motorists are prohibited from using the paved shoulder except in an emergency. According to A Guide on Geometric Design of Roads (1986), the width of the paved shoulder is variable (1.5 to 3.0 meters) and it is depending on the standards of the attached roads. motorcycle accidents and related fatal injuries in these countries are also increasing (Nur Sabahiah A.S and Satoshi Fujii, 2011).

In addition, one of the factors that contribute to the road accident is in term of environment. Researchers have difference opinion regarding to the term of environment. First researcher define environment as the weather condition that give effect during the accident occur, for example accident frequency increase in wet weather condition ( Julia,1998). Second researcher define environment as condition of the road, roads should be built to suit their function (Marizwan Abdul Manan, 2014). Third researcher define environment as the location of the road. According to the researcher accident usually occur along the straight road and fatal side collision (Ghazali Masuri and Khairil Anuar, 2011).

\section{RESULTS AND DISCUSSION}

The data has been analysed for overall three factors which is human behaviour, road vehicles, and environment factors. The factor analysis for below factors is the possibility of UTM students involved in motorcycle accidents has been studies. The scree plot is a graph of the eigenvalues against all the factors. The graph is useful for determining how many factors to retain. The point of interest is where the curve starts to flatten. It can be seen that the curve begins to flatten between factors 3 and 4 . Note also that factor eight has an eigenvalue of less than 1, so only two factors have been retained. Based on the table and graph above it has shown two main factors that show the high percentage of variance. One is for over speeding and second is usage of alcohol or drug. These two factors are the main contribution for the accident in Malaysia for human behaviour.

The scree plot is a graph of the eigenvalues against all the factors. The graph is useful for determining how many factors to retain. The point of interest is where the curve starts to flatten. It can be seen that the curve begins to flatten between factors 3 and 4 . Note also that factor eight has an eigenvalue of less than 1, so only two factors have been retained. Based on the table and graph above it has shown two main factors that show the 
high percentage of variance. One is for over speeding and second is usage of alcohol or drug. These two factors are the main contribution for the accident in Malaysia for human behaviour. On the road human attitude that likes to drive over speed can cause an accident to other road user. When they drive over speed, sometime they tend to loss control on their vehicles and can hits other road user especially for motorcycle rider. Statistics have shown that there are a high number of percentages of accident in Malaysia is involve motorcycle rider. Second factor that show a high percentage is usage of alcohol or drug. When driver take alcohol or drug they have a tendency to lose control of their self. While driving they also tend to loss control on their vehicles and can hit other road user especially for motorcycle driver.

Total Variance Explained

\begin{tabular}{|c|c|c|c|c|c|c|c|c|c|}
\hline \multirow[t]{2}{*}{$\begin{array}{l}\text { Componen } \\
\mathrm{t}\end{array}$} & \multicolumn{3}{|c|}{ Initial Eigenvalues } & \multicolumn{3}{|c|}{$\begin{array}{c}\text { Extraction Sums of Squared } \\
\text { Loadings }\end{array}$} & \multicolumn{3}{|c|}{$\begin{array}{c}\text { Rotation Sums of Squared } \\
\text { Loadings }\end{array}$} \\
\hline & Total & $\begin{array}{c}\% \text { of } \\
\text { Varianc } \\
\mathrm{e}\end{array}$ & $\begin{array}{l}\text { Cumulativ } \\
\text { e } \%\end{array}$ & Total & $\begin{array}{c}\% \text { of } \\
\text { Varianc } \\
\mathrm{e}\end{array}$ & $\begin{array}{l}\text { Cumulativ } \\
\text { e } \%\end{array}$ & Total & $\begin{array}{c}\% \text { of } \\
\text { Varianc } \\
\mathrm{e}\end{array}$ & $\begin{array}{l}\text { Cumulativ } \\
\text { e } \%\end{array}$ \\
\hline 1 & $\begin{array}{r}8.21 \\
3\end{array}$ & 37.333 & 37.333 & $\begin{array}{r}8.21 \\
3\end{array}$ & 37.333 & 37.333 & $\begin{array}{r}3.93 \\
3\end{array}$ & 17.877 & 17.877 \\
\hline 2 & $\begin{array}{r}2.01 \\
8\end{array}$ & 9.171 & 46.504 & $\begin{array}{r}2.01 \\
8\end{array}$ & 9.171 & 46.504 & $\begin{array}{r}3.16 \\
8\end{array}$ & 14.399 & 32.277 \\
\hline 3 & $\begin{array}{r}1.34 \\
6\end{array}$ & 6.119 & 52.622 & $\begin{array}{r}1.34 \\
6\end{array}$ & 6.119 & 52.622 & $\begin{array}{r}2.97 \\
1\end{array}$ & 13.505 & 45.782 \\
\hline 4 & $\begin{array}{r}1.21 \\
8\end{array}$ & 5.534 & 58.157 & $\begin{array}{r}1.21 \\
8\end{array}$ & 5.534 & 58.157 & $\begin{array}{r}2.72 \\
3\end{array}$ & 12.375 & 58.157 \\
\hline 5 & .969 & 4.404 & 62.560 & & & & & & \\
\hline 6 & .860 & 3.910 & 66.470 & & & & & & \\
\hline 7 & .818 & 3.719 & 70.189 & & & & & & \\
\hline 8 & .706 & 3.209 & 73.397 & & & & & & \\
\hline 9 & .618 & 2.810 & 76.207 & & & & & & \\
\hline 10 & .608 & 2.765 & 78.972 & & & & & & \\
\hline 11 & .575 & 2.614 & 81.586 & & & & & & \\
\hline 12 & .563 & 2.559 & 84.145 & & & & & & \\
\hline 13 & .472 & 2.144 & 86.289 & & & & & & \\
\hline 14 & . 470 & 2.138 & 88.427 & & & & & & \\
\hline 15 & .436 & 1.983 & 90.410 & & & & & & \\
\hline 16 & .406 & 1.846 & 92.256 & & & & & & \\
\hline 17 & .382 & 1.734 & 93.990 & & & & & & \\
\hline 18 & .314 & 1.427 & 95.417 & & & & & & \\
\hline 19 & .296 & 1.347 & 96.764 & & & & & & \\
\hline 20 & .262 & 1.191 & 97.955 & & & & & & \\
\hline 21 & .255 & 1.159 & 99.114 & & & & & & \\
\hline 22 & 195 & .886 & 100.000 & & & & & & \\
\hline
\end{tabular}

\section{CONCLUSION AND RECOMMENDATION}

Motorcycles crashes are endless issue. We should take proactive steps to reduce and prevent this scenario because it is better to prevent than cure. Motorcycles crashes could be avoided if all parties regardless of individual, community, Government and NonGovernment as well as the united mobilize an effective effort to address the issues of road accidents. A minimum accident rates could raise the prestige and image of Malaysia in 
Zahid Sultan, Noor Irdiana Ngadiman, Fara Dela A.Kadir, Nuur Fathin Roslan \& Mehdi Moeinaddini Factor Analysis of Motorcycle Crashes in Malaysia

the world stage in order our country is respected, high esteem and labelled as a country that adopts effectively road laws and legislation

The factor analysis shows that human behavior factors likes over speeding, usage of alcohol, less priority on the road for motorcyclist and sudden change of lanes and direction are contributed highest percentages of motorcycle accidents. Therefore, this research is come out with few recommendations in order to reduce the number of motorcycles accidents in Malaysia.

According to human behaviour factor, over speeding is higher percentage of variance with $28.975 \%$. It is shows human attitudes likes to drive over speed on the road which can cause an accidents. Therefore, Road Transport Department of Malaysia (RTDM) together with Royal Malaysia Police (RMP) especially under Road Traffic Department should co-operate implement an installation speed limit control detector. The detector should be installed inside the automobile in order to control the speed limit. Once they break the speed limit, the detector will send a signal to TDM and RMP for their further actions. The detector shall be registered by follow car chassis number. Hence, summons can be issued to the offender who has driven over speed limit. Second recommendation is Road Transport Department of Malaysia (RTDM) should implement a Continuous Defensive Driving Course and Training to all drivers' license. This is an approach to ensure all drivers are obey with traffic rules as well as encourage them to remain proper driving methods which has been sets by RTDM. As we know, driving course and training only need to be taken once during in the learning process before driving test is taken. Therefore, RTDM should introduce this course at least after ten years the drivers having driving license. The course should have a test whereby, the drivers should pass the test in order to ensure their driving license is valid, otherwise the license will terminated and they should starts from the beginning.

Third, Government Agencies should play a role in enforcement and implementation of Legislation must be more effective. Legislation can be categorized into two major parts, namely the establishment of law and law enforcement. Legislation is a legal basis. Laws established it should have a psychological impact to road users and it should be practical for police to implement. With the law which carries the most daunting road users will afraid to engage in misconduct. Those stubborn road users and threaten to public safety, they can be prevented to do so with the mechanism of prison by law. Effective enforcement can indeed enhance the credibility of laws and may impact on public road safety. Therefore, the Authorities should be equipped with various and good facilities during carry out an enforcement. Hence, penalties must be imposed those anyone who dared to violet the rules of the road. Besides that, improve signage on the road also important in order to reduce number of motorcycle accidents. Every motorist is trying to go somewhere, and many of them are not sure how to go there. Road signage plays important roles because it can give a direction and information to the motorist either their need to turn or not to turn while him or her on riding. In order to reduce road accidents especially for motorist, the respective department need to improve road signage especially in rural highway and suburban area. Many rider at rural area are not aware about the road signage because there assume he or she at their own area or own village. However, at the early stage of application of driving license also are required the driving candidate to attend the theory class and computer test regarding road signage information. 
Therefore, by improving road signage along way of the road, it can help riders more alert and aware on road direction and situation.

The authorities must implement the rules of compulsory of using safety jacket for motorist. The safety jacket must be in bright colour or glow in the dark. It is to make others rider or drivers aware about them on the road especially during night time. When the riders wear dark jacket or t-shirt, the possibility people not aware and alert the objects is high. Therefore, using safety jacket when riding can reduce the percentage of rider involve in a major accidents. The others ways to reduce motorcycle accidents in Malaysia is to build a specific lanes for motorcyclist. Motorcycle is a small object on the road especially compare to lorry, bus, or car. Sometime, others driver are not alert about existence of riders on the road. Therefore, build a specific lane of riders or cyclist is a good ways to them to ride because the riders no need to crowded and butted with other vehicles on the same road. Therefore, it can reduce the number of accidents especially during peak hours.

On the other hands, the effective of public transportation can encourage people to use public transportation services. Most of motorcycle riders prefer to use their own motorcycle because it is easy for them to move from one place to another place. When there are a high number of vehicles on the road, the percentage of motorcycle that will involve in accident is high. By make public transportation more effective and efficiency we can attract more motorcycle rider to switch from rider motorcycle to use public transportation hereby we can reduce the number of vehicles on the road and less risk that motorcycle will involve in accident. Besides that, to avoid many license holder is Malaysia; the authorities may be able to increase the age limit to apply the license. Currently in Malaysia, one the requirement if Malaysia citizen want to apply for motorcycle licence is the applicant must be 16 years old. In this age the motorcycle rider is too young, sometimes their action on the road can cause an accident because at this age they are not mature enough. One of the recommendations to reduce the number of accident, Jabatan Pengankutan Jalan (JPJ) can increase the age limit to apply the motorcycle licence from 16 years old to 18 years old. At age 18, the teenage is more matured; their action on the road can reflect their riding skills, more patient and can tolerance with other. Here we can reduce the percentage the vehicles will involve in accident. Last but not lease, Malaysia government by its agency can make a campaign of safety awareness from time to time to give awareness to Malaysia citizen about the safety on the road. Statistics has shown that the higher factor that contributes to motorcycle accident is because of human behaviour its self on the road. By make the campaign, we can educate and give awareness on how our behaviour can cause an accident and what action can we take to reduce the risk involve in the accident.

\section{ACKNOWLEDGEMENT}

The authors wish to thank all of those who have supported this research for their useful comments during its completion. In particular, we would like to acknowledge the UTM Management Centre (RMC). The funding for this project is made possible through the research grant obtained from Ministry of Education (MoE) Malaysia under GUP the Universiti Teknologi Malaysia (Grant no: Q.J130000.2721.00K99). The authors would like to thank Ministry of Transport, Malaysia, for providing information and data. We are also like to thank referees for the fruitful comments. 
Zahid Sultan, Noor Irdiana Ngadiman, Fara Dela A.Kadir, Nuur Fathin Roslan \& Mehdi Moeinaddini

Factor Analysis of Motorcycle Crashes in Malaysia

\section{REFERENCES}

Ahmed, A., Sadullah, A. and Yahya, A. (2014). Accident Analysis Using Count Data for Unsignalized Intersections in Malaysia. Procedia Engineering, 77, pp.45-52.

Ayinla, O., Gboyega, A., Adefunke Sarah, E., Solomon Olusegun, O. and John Olugbenga, A. (2012). Factors Influencing High Rate of Commercial Motorcycle Accidents in Nigeria. American International Journal of Contemporary Research, 2(11), pp.131139.

Chuthamat Laksanakit, (2013), Impact of Motorcycle Defects on Motorcycle Safety in Thailand. Journal of Society for Transportation and Traffic Studies (JSTS), Vol.5, No.1.

Dixon, C. J. and B. Leach (1978). "Questionnaires and Interviews In Geographical Research."

Julia B. Edwards, 1998, The relationship between road accident severity and recorded weather. Journal of Safety Research, Vol.29, No.4.

Karem, A. (2003). Review of global menace of road accident with special reference to Malaysia -A social perspective. Malaysian Journal of Medical Sciences, , 10(2), pp.3139.

Kumar, R. (2005). Research Methodology - A step-by-step Guide for Beginners. 2md edition, Singapore, Pearson Education.

Ministry of Transport Malaysia, (2010). Malaysia transport statistics 2010.

Mohamad Ghazali Masuri and Khairil Anuar Md Isa, (2011), Children, Youth and Road Environment. Asian Journal of Environment -Behaviour Studies, Vol.2, No.6.

Morabia, A., Zhang, F., Kappil, M., Flory, J., Mirer, F., Santella, R., Wolff, M. and Markowitz, S. (2012). Biologic and epigenetic impact of commuting to work by car or using public transportation: A caseâ€"control study. Preventive Medicine, 54(3-4), pp.229-233.

Muhammad Marizwan Abdul Manan and András Várhelyi, (2012), Motorcycle fatalities in Malaysia, 36, 30-39.

Muhammad Marizwan Abdul Manan, (2014), Motorcycles entering from access point and merging with traffic on primary roads in Malaysia: Behavioral and road environment influence on the occurrence of traffic conflicts. Accident Analysis and Prevention, 70,301-313.

Newman, P. and Matan, A. (2012). Human mobility and human health. Current Opinion in Environmental Sustainability, 4(4), pp.420-426.

Nur Sabahiah A.S and Satoshi F, (2011), Factors affecting motorcyclist's speeding behaviour in different types motorcycle lanes: A study from psychological perspectives. Proceedings of the Eastern Asia Society for Transportation Studies, Vol 8.

Polit, D. F., \& Hungler, B. P. (1999). Nursing research: Principles and methods (6th ed.). Philadelphia: Lippincott.

Remenyi, D., B. William, Money \& Swartz. (1998). Doing Research in Business Management, London: Sage Publication.

Salkind, N. J. (2003). Exploring Research, New Jersey: Prentice Hall

Shamsuri, S. (2004). Research Methods for the Social Science, Kuala Lumpur, Malaysia: DSS.

Solecka, K. and $\AA » a k$, J. (2014). Integration of the Urban Public Transportation System with the Application of Traffic Simulation. Transportation Research Procedia, 3, pp.259268 